Ks. Brunon ZGRAJA*

\title{
SYMBOLIKA KSIĘŻYCA W ENARRATIONES IN PSALMOS ŚW. AUGUSTYNA
}

W literaturze patrystycznej fundamentalnym punktem odniesienia refleksji teologicznej było Pismo Święte ${ }^{1}$, do wyjaśnienie którego oprócz literalizmu używano także metody alegorycznej ${ }^{2}$. Metoda ta, rozumiana w sensie szerokim jako ogólnie pojęte przenośne thumaczenie tekstu biblijnego była stosowana $\mathrm{w}$ chrześcijaństwie od samego początku³ . Pozwalała ona, z jednej strony, na wydobycie $\mathrm{z}$ tekstu biblijnego jak najgłębszego sensu ${ }^{4}$, zaś z drugiej strony ponieważ teologia Ojców Kościoła była w przeważającej mierze egzegezą ${ }^{5}$ kreowała bez wątpienia treść teologicznych dociekań. Opatrznościowe zadanie Ojców Kościoła, którzy jako pierwsi podjęli racjonalną refleksję nad danymi Objawienia, stając się tym samym światłymi prekursorami zrozumienia wiary, polegało jednak nie tylko na pogłębianiu zbawczej prawdy, ale też na przedstawieniu wiary ludzkim językiem, zdolnym do wyrażenia Boskiej treści Objawienia, zachowującym jej tożsamość i transcendencję. Znaczy to, iż alegoryczna perspektywa lektury Pisma Świętego, wpisująca się w pierwszym rzędzie w intellectus fidei, które należy do istoty autentycznej teologii, tworzonej nierzadko w opozycji do mnożących się doktryn heretyckich ${ }^{7}$, odzwierciedla jeszcze jeden

* Ks. dr Brunon Zgraja - adiunkt w Katedrze Historii Kościoła i Patrologii na Wydziale Teologii Uniwersytetu Opolskiego; e-mail: zgrb@op.pl.

${ }^{1}$ Por. M. Fiedrowicz, Principes de l'interprétation de l'Écriture dans l'Église ancienne, Bern 1998, IX

2 Przeplatanie się literalizmu i alegoryzmu w egzegezie patrystycznej ukazał M. Simonetti, Między dosłownościq a alegoriq. Przyczynek do historii egzegezy patrystycznej, thum. T. Skibiński, Kraków 2000. Por. K. Romaniuk, Biblia u Ojców Kościoła a Ojcowie Kościoła w studium Biblii, RTK 22 (1975) z. 1, 68-69.

${ }^{3}$ Metodę alegoryczną, jak uważa M. Simonetti (L'allegoria in Celso. Filone e Origine, w: Tradizione e innovazione nella cultura greca da Omero all'eta ellenistica. Scritti in onore di Bruno Gentili, a cura di R. Pretagostini, vol. 3, Roma 1993, 1137), stosował już św. Paweł, który nawiązywał do praktyki egzegetycznej judeo-helleńskiej.

${ }^{4}$ Por. R.D. Witherup, Wspótczesna krytyka literacka czy powrót do egzegezy patrystycznej?, VoxP 9 (1989) t. 16, 180-188.

${ }^{5}$ Por. B. Studer, Schola christiana. Die Theologie zwischen Nizäa und Chalcedon, Paderborn 1998, 26-30.

${ }^{6}$ Por. Instrukcja o studium Ojców Kościoła w formacji kapłańskiej 34, 2.

${ }^{7}$ Por. C. Corsato, Biblia w interpretacji Ojców Kościoła, thum. K. Kubis, Kraków 2007, 13. 
wymiar życia Kościoła, a mianowicie posługę duszpasterska. Alegorystyka służyła bowiem nie tylko rozwojowi myśli teologicznej, lecz była wykorzystywana także w działalności liturgiczno-homiletycznej Kościoła. Pozwalała ona na odkrycie przed słuchaczem różnych pokładów znaczeń czytanych w czasie liturgii tekstów Pisma Świętego, dostosowując tym samym ich wykładnię do rodzaju i wymagań audytorium. Mistrzem alegorycznej interpretacji Pisma Świętego, streszczającej się w zasadzie św. Grzegorza Wielkiego: „divina eloquia cum legente crescunt", był bez wątpienia św. Augustyn". Znając bowiem doskonale Pismo Święte, a zarazem rozumiejąc obecny w nim świat obrazów i symboli, starał się, poprzez alegoryczną ich interpretację ${ }^{10}$, dać swoim wiernym w komentarzach do ksiagg Starego i Nowego Testamentu wykładnię różnych teologicznych zagadnień, ukazując tym samym natchnione księgi jako przewodnik w ich poznawaniu ${ }^{11}$. Na szczególną uwagę zasługuje w tym względzie największe dzieło egzegetyczno-homiletyczne Augustyna, jakim jest Enarrationes in $P_{\text {salmos }}{ }^{12}$. Dzieło to, zawierające teksty homilii wygłaszanych w latach 391$415^{13}$, stanowi niewyczerpalną kopalnię nauki teologicznej ${ }^{14} \mathrm{i}$ zadziwia nie tyle szerokim wachlarzem objaśnianych $\mathrm{w}$ nich zagadnień, co przede wszystkim ich thumaczeniem za pomocą alegorycznych wywodów ${ }^{15}$, w których nadaje on nowy, często wbrew jakimkolwiek oczekiwaniom i przesłankom, chrześcijański sens liczbom, rzeczom, roślinom, drzewom, zwierzętom i różnym nazwom.

${ }^{8}$ Por. Gregorius Magnus, Moralia in Iob 20, 1, 1, PL 76, 136. Por. K. Bardski, Patristic Interpretation of Scripture and Modern Biblical Studies. Methodological Suggestions, „Folia Orientalia” 34 (1998) 24-26.

${ }^{9}$ Por. R. Doni, Święty Augustyn. Poszukiwanie prawdy. Biografia, thum. L. Rodziewicz, Kraków 2003, 182; K. Panuś, Historia kaznodziejstwa, Kraków 2004, 73; Simonetti, Między dostownościq a alegoriq, s. 349,361 i 364 .

${ }^{10}$ Por. L.C. Ferrari, Symbols of Sinfulness in Book II of Augustine's „,Confessiones”, AugSt 2 (1971) 93-104; R.S. Vergés, La Encarnación del Verbo y la Iglesia en San Agustin. Teología de símbolos bíblico-eclesiales, EE 42 (1967) 73-112; M. Comeau, Saint Augustin exégèt du quatrième Évangile, Paris 1930, 113-127.

${ }^{11}$ Por. J. Sulowski, Wstęp, w: Św. Augustyn, Objaśnienia Psalmów, PSP 37, Warszawa 1986, 24-25; D.S. Chidester, The Symbolism of Learning in St. Augustine, HTR 76 (1983) 73-90.

${ }^{12}$ Enarrationes in Psalmos to jedyny kompletny komentarz do Księgi Psalmów z okresu patrystycznego. Por. H.R. Drobner, The Fathers of the Church. A Comprehensive Introduction, transl. by S.S. Schatzmann, Peabody (Mass.) 2007, 414.

${ }^{13}$ Por. S. Pieszczoch, Patrologia. Wprowadzenie w studium Ojców Kościoła, Gniezno 1998, 114. Według A. Wilmarta (La tradition des grandes ouvrages de saint Augustin, IV: Les Enarrationes, w: MA II, Roma 1931, 295), dzieło Enarrationes in Psalmos zawiera 86 tekstów dyktowanych i 119 wygłoszonych. Por. Corsato, Biblia w interpretacji Ojców Kościoła, s. 196, nota 57. E. Stanula (Św. Augustyn. Wybór mów (kazania świqteczne i okolicznościowe), w: E. Stanula, Eseje patrystyczne, oprac. I. Salamonowicz-Górska, Warszawa 2014, 380-381) określa Enarrationes in Psalmos mianem popularnych kazań.

${ }^{14}$ Por. A. Trapè, Święty Augustyn - człowiek - duszpasterz - mistyk, thum. J. Sulowski, Warszawa 1987, 147.

${ }^{15}$ Por. Sulowski, Wstęp, s. 28 i 31-32; Altaner, s. 562; Corsato, Biblia w interpretacji Ojców Kościoła, s. 197; Pieszczoch, Patrologia, s. 114. 
Występująca w Objaśnieniach Psalmów symbolika, która nierzadko wymyka się logicznym schematom dotyczy także ciał niebieskich, w tym także i księżyca, którego motyw obecny w literaturze starożytnego Kościoła nie stanowił jedynie części opisów piękna stworzonego świata, ale był pomocny autorom chrześcijańskim głównie $\mathrm{w}$ objaśnianiu tajemnicy Kościoła ${ }^{16}$. Czy było tak i w przypadku biskupa Hippony? Podjęte na gruncie polskim nieliczne badania nad symboliką lunarną w twórczości Augustyna nie dają w tym względzie wyczerpującej odpowiedzi. Badania te stanowią bowiem jedynie mały fragment szerokiego projektu badawczego, ukazującego symbolikę księżyca w średniowiecznej poezji liturgicznej oraz u niektórych pisarzy wczesnochrześcijańskich, co pozwala przypuszczać, iż przeprowadzone w nich w ograniczonych ramami artykułu analizy nie oddają wszystkich treści, jakie kryją się w Augustynowej alegorycznej interpretacji motywu księżyca ${ }^{17}$. Spostrzeżenie to potwierdza fakt, iż w dokonanych badaniach pominięto szereg wypowiedzi Augustyna na temat księżyca z interesującego nas dzieła Enarrationes in Psalmos, co uprawnia nas do podjęcia $\mathrm{w}$ niniejszych artykule zagadnienia symboliki lunarnej zaprezentowanej przez biskupa Hippony w jego Objaśnieniach Psalmów.

1. Księżyc metaforą Boga Stwórcy. Religijna interpretacja księżyca powszechna już $\mathrm{w}$ religiach niechrześcijańskich ${ }^{18}$, $\mathrm{z}$ pewnością nieobca epoce Augustyna, której świat pojęć i język zakorzeniony był w kulturze świata antycznego, pozwoliła mu bez ryzyka nieporozumień nadać księżycowi w Enarrationes in Psalmos teologiczną wymowę, a tym samym naświetlić przy jego pomocy treści wiary dotyczące m.in. Boga Stwórcę. Sakralny wymiar symboliki księżyca, co warto podkreślić, nie oznaczał jednak przyzwolenia na jego ubóstwianie ${ }^{19}$, tak powszechnego w kulturze pogańskiej ${ }^{20}$. Można natomiast przypuszczać, iż interpretacja księżyca pod kątem religijnym miała raczej uświadamiać chrześcijanom możliwość odkrywania w otaczającym ich świecie odbicia Bożych tajemnic ${ }^{21}$. Znaczy to tym samym, że jedną z dróg prowadzących do poznania Boga są niewątpli-

\footnotetext{
${ }^{16}$ Por. H. Rahner, Simboli della Chiesa. L'eeclesiologia dei Padri, trad. L. Pucci - A. Pompei, Roma 1971, 169-229.

${ }^{17}$ Por. T. Kaczmarek, „Mysterium lunae” w eklezjologii starożytnego Kościoła, „Teologia i Człowiek” 17 (2011) 43-59; tenże, ,, Seges Ecclesiae”. Eklezjalny wymiar męczeństwa w nauczaniu św. Augustyna, Toruń 2010, 61-63; J. Sawicka, Symbolika lunarna w średniowiecznej poezji liturgicznej, „Pamiętnik Literacki” (2002) z. 3, 5-35.

${ }_{18}$ Por. D. Forstner, Świat symboliki chrześcijańskiej, thum. W. Zakrzewska - P. Pachciarek - R. Turzyński, Warszawa 1990, 97; M. Lurker, Słownik obrazów i symboli biblijnych, thum. K. Romaniuk, Poznań 1989, 103-104.

${ }^{19}$ Por. Augustinus, Enarrationes in Ps. 62, 1, ed. D.E. Dekkers - I. Fraipont, CCL 39, Turnhout 1956, 793; 88 (1), 7, CCL 39, 1224; 112, 3, ed. D.E. Dekkers - I. Fraipont, CCL 40, Turnhout 1956, $1631 ; 113$ (2), 4, CCL 40, 1644.

${ }^{20}$ Por. M. Eliade, Traktat o historii religii, thum. J. Wierusz-Kowalski, Warszawa 1966, 160.

${ }^{21}$ Por. J.M. Dermott, Lune - symbolisme religieux, DSp IX 1192.
} 
wie dzieła stworzenia ${ }^{22}$. Augustyn uświadamia swoim słuchaczom tę prawdę w komentarzu do Psalmu 73:

„Kto potrafi niech dostrzega, kto nie potrafi niech wierzy, że Bóg istnieje. A chociaż nawet, kto może widzi, to czy oczyma ciała? Umysłem widzi, sercem widzi. Wszak to nie słońce i księżyc pokazywał ten, który powiedział: «Błogosławieni czystego serca, albowiem oni Boga oglądać będą» (Mt 5, 8). Natomiast serce nieczyste nie jest nawet zdolne do wiary, żeby mogło uwierzyć w to, czego nie widzi. Powiada, nie widzę tego; w co mam uwierzyć? Duszę twoją bowiem widać, jak wnioskuję! Głupcze! Ciało twoje widać. Kto widział twoją duszę? Skoro więc tylko twoje ciało widać, czemuś nie został pochowany? Dziwi się czemu powiedziałem: Skoro tylko twoje ciało widać, czemuś nie został pochowany? I odpowiada, tyle bowiem wie: Ponieważ żyję. Skąd wiem, że żyjesz, skoro twojej duszy nie widzę? Skąd wiem? Odpowiesz: Ponieważ rozmawiam, chodzę, robię. Głupcze! Z postępowania ciała poznaję żyjącego; a z dzieła stworzenia nie potrafię poznać Stwórcy!"’23.

Orzekanie o Bogu w oparciu o dzieła stworzenia, w tym także o motyw księżyca, nie dokonuje się poprzez samo ich odnoszenie do Boga Stwórcy. Augustyn rysuje bowiem obraz Boga w oparciu o ich przymioty i funkcje, w których dostrzega metaforę przymiotów Boga Stwórcy, nierzadko możliwą do uchwycenia dopiero na tle szerszego kontekstu jego homiletycznego wywodu. U podstaw owego orzekania o Bogu na podstawie dzieł stworzenia leży przekonanie Augustyna, iż to, co zostało przez Boga stworzone nie może nie być do Niego absolutnie i całkowicie niepodobne ${ }^{24}$. Takie założenie pozwala biskupowi Hippony uzmysłowić słuchaczom swoich kazań fakt, iż Bóg jest Pięknem ${ }^{25}$. Piękno stworzeń i każde piękno porządku ziemskiego odsyła bowiem do Stwórcy. Innymi słowy, piękno świata staje się metaforą Boga, czyniąc z Niego źródło, które samo musi być pięknem:

${ }^{22}$ Por. Augustinus, Enarrationes in Ps. 144, 6, CCL 40, 2109; Rz 1, 20.

${ }^{23}$ Augustinus, Enarrationes in Ps. 73, 25, CCL 39, 1021: „Videat qui potest, credat qui non potest, esse Deum. Etsi videt qui potest, numquid oculis videt? Intellectu videt, corde videt. Non enim solem et lunam volebat ostendere, qui dicebat: Beati mundo corde, quoniam ipsi Deum videbunt. Immundum autem cor nec ad fidem idoneum, ut quod non potest videre vel credat. Non video, inquit: quid crediturus sum? Anima enim tua videtur, ut opinor! Stulte! corpus tuum videtur; animam tuam quis videt? Cum ergo corpus tuum solum videatur, quare non sepeliris? Miratur quia dixi: Si corpus tantum videtur, quare non sepeliris? Et respondet (sapit enim ad hoc): Quia vivo. Unde scio quia vivis, cuius animam non video? unde scio? Respondebis: Quia loquor, quia ambulo, quia operor. Stulte! ex operibus corporis agnosco viventem; ex operibus creaturae non potes agnoscere Creatorem!", thum. J. Sulowski, PSP 39, Warszawa 1986, 324.

${ }^{24}$ Por. tenże, Confessiones 11, 4, 6, PL 32, 811.

${ }^{25} \mathrm{O}$ utożsamianiu Boga z pięknem pisze Augustyn m.in. w dziele O Trójcy Świętej (Augustinus, De Trinitate 15, 5, 8; PL 42, 1062). Więcej na temat Boga jako Piękna zob. P. Turzyński, Piękno $w$ teologii świętego Augustyna. Próba systematyzacji augustyńskiej estetyki teologicznej, Radom 2013, 415-463; J. Tscholl, Gott und das Schöne beim hl. Augustinus, Heverlee - Leuven 1967; tenże, Dio e il Bello in Sant'Agostino, Milano 1996. 
„Zbierz się w sobie, i szukaj Sprawcy tego wszystkiego, co ci się zewnętrznie podobało. Nic nie ma lepszego na ziemi na przykład od tego niż to, czy tamto: złoto, srebro, zwierzęta, drzewa, przyjemności, myśl o całej ziemi. Cóż na niebie piękniejszego od słońca, księżyca, gwiazd? Pomyśl o wszystkim, co na niebie. To wszystko razem jest bardzo dobre, gdyż Bóg stworzył wszystko bardzo dobre. Zewsząd dochodzi cię piękno dzieła, które ci mówi o Twórcy. Podziwiasz budowlę, podziwiaj Budowniczego. Nie zajmuj się tym, co zostało zrobione, żebyś stracił z oczu tego, który to uczynił"26.

Mając na uwadze powyższy fakt, a mianowicie ujawnienie się Boga jako Piękna poprzez piękno stworzenia, wypada zauważyć, iż owo ujawnienie się nie było podyktowane żadną koniecznością. Akt stwórczy Boga, poprzez który dokonało się objawienie Jego przymiotów był aktem całkowicie dobrowolnym. Bóg w stwarzaniu nie był zdeterminowany ani co do jakiegoś faktu, ani co do jakiegoś bytu. Przekonaniu temu daje wyraz Augustyn w komentarzu do Psalmu 113, gdzie w odniesieniu do dostrzeganego na niebie słońca i księżyca stwierdza: „«Na niebie i na ziemi uczynił wszystko, co zechciał»" ${ }^{27}$. Co więcej, Bóg ,nie potrzebuje też swoich dzieł, żeby się na nich oprzeć, żeby przetrwać. Trwa bowiem w swej wiekuistości, i w niej trwając, uczynił wszystko, co zechciał w niebie i na ziemi. I one go nie podtrzymywały, i dlatego zaistniały, ponieważ nie istniejąc nie mogłyby go nosić. Otóż będąc w nich, one uzależnione są od niego, on zaś nieogarniony ich nie potrzebuje"28. Słońce, jak również i księżyc, stworzył więc Bóg nie dla własnej korzyści, zaś sam akt stwórczy i powstały dzięki niemu między innymi księżyc, wskazują na samowystarczalność Boga, Jego wolność i całkowitą niezależność.

Motyw księżyca posłużył także Augustynowi do ukazania Boga Stwórcy jako Dobra wszystkich dóbr. W kontekście rozważań poświęconych Bogu jako Dobru Augustyn stwierdza:

${ }^{26}$ Augustinus, Enarrationes in Ps. 145, 5, CCL 40, 2108: „,colligere ad te ipsam: quidquid tibi foris placebat, quaere quem habeat auctorem. Nihil melius in terra, verbi gratia, quam hoc et illud: aurum, argentum, animalia, arbores, amoenitates, totam terram cogita. Quid melius in coelo sole, luna, sideribus? Totum coelum cogita. Omnia ista simul bona valde, quia fecit Deus omnia bona valde. Undique pulchritudo operis, quae tibi commendat artificem. Miraris fabricam, ama fabricatorem. Non occuperis in eo quod factum est, et recedas ab illo qui fecit", thum. J. Sulowski, PSP 42, Warszawa 1986, 305.

${ }^{27}$ Tamże 113(1), 14, CCL 40, 1640: „In coelis et in terra omnia quaecumque voluit fecit”, thum. J. Sulowski, PSP 41, Warszawa 1986, 188.

${ }^{28}$ Tamże, CCL 40, 1640-1641: „Nec indiget operibus suis, tamquam in eis collocetur, ut maneat; sed in sua aeternitate persistit, in qua manens omnia quaecumque voluit fecit in coelis et in terra: neque enim iam eum portabant, ut ab eo fieri possent; quando, nisi fierent, eum portare non possent. Ergo in quibus est ipse, tamquam indigentia continet, non ab eis tamquam indigens continetur”, PSP 41, 188. 
„Przekonuję się, że wśród stworzeń niebo jest dobre, księżyc jest dobry, gwiazdy są dobre. Dobra jest ziemia, to co się na niej rodzi i korzeniami w niej tkwi też jest dobre. Dobre to co chodzi i porusza się, to co lata w powietrzu i pływa w wodzie też jest dobre. Powiem, że i człowiek jest dobry. $[\ldots]$ powiadam, że i anioł jest dobry [...]. Wszystkie te rzeczy nazywamy dobrymi, ale wraz ze swoimi nazwami: niebo dobre, anioł dobry, człowiek dobry. Kiedy jednak zwracam się ku Bogu, myślę, że nie można nic innego o Nim powiedzieć jak: Dobry. Sam bowiem Pan Jezus powiedział: «Nikt nie jest dobry, poza samym tylko Bogiem» (Mk 10, 18). Czyż przez to nie pobudził nas do zapytania i rozróżnienia, czym jest dobro dzięki innemu dobru i dobro samo w sobie. Jakimże zatem dobrem jest to, od którego pochodzą wszystkie dobra? W ogóle nie znajdziesz żadnego dobra, które nie pochodziłoby od Niego. Dobro sprawiające rzeczy dobre, jak właściwie «jest», tak że jest Dobrem w sposób właściwy"29.

Jak nie trudno zauważyć w powyższej wypowiedzi Augustyna, znamienne połączenie dobra z istnieniem dowodzi, że księżyc i wszystkie inne dzieła stworzone przez Boga są dobre, gdyż pochodzą od Boga, który sam jest Dobrem ${ }^{30}$. Co więcej, stworzenia te widziane jako dobre każą myśleć i mówić o Bogu jedynie jako o Tym, który jest Dobrem. Dobro stworzeń wskazuje więc na Boga jako Dobro, co bez wątpienia wyrasta z przekonania Augustyna, że wszystkie rzeczy stworzone są realizacją boskich idei i noszą na sobie ślad podobieństwa do Boga. Piękno fizyczne stworzenia jest odbiciem piękna Boga, porządek

${ }^{29}$ Tamże 134, 4, CCL 40, 1939-1940: „Invenio in creatura coelum bonum, solem bonum, lunam bonam, stellas bonas; terram bonam, quae gignuntur in terra et radicibus nixa sunt, bona; quae ambulant et moventur, bona; quae volitant in aere et natant in aquis, bona. Dico et hominem bonum: [...]. Dico et angelum bonum [...]. Omnia ista dico bona, sed tamen cum suis nominibus; coelum bonum, angelum bonum, hominem bonum: ad Deum autem cum me refero, puto melius nihil dicere quam bonum. Ipse quippe Dominus Iesus Christus dixit: Homo bonus; et ipse item dixit: Nemo bonus, nisi unus Deus. Nonne stimulavit nos ad quaerendum et ad distinguendum quid sit bonum alio bono bonum, et bonum seipso bonum? Quam ergo bonum est a quo sunt omnia bona? Omnino nullum invenias bonum quod non ab illo sit bonum. Bonum bona faciens sicuti est proprie, sic et bonum est proprie”, PSP 42, 42-43. Por. tamże 44, 4, ed. D.E. Dekkers - I. Fraipont, CCL 38, Turnhout 1965, 517.

${ }^{30}$ Augustyn, ,uznając uniwersalizm dobra, był pod wpływem pitagoreizmu, neoplatonizmu i Biblii. Od pitagorejczyków przejął finalistyczną interpretację kosmosu, co prowadziło logicznie do twierdzenia, że wszystko jest ze swej natury dobre. Plotyn, przyjmując teorię emanacjonizmu, genezę transformacji świata wywodził z triady: Jednia, Umysł, Dusza, za istotny atrybut AbsolutuJedni uznał dobro, określając je jako «nad-dobro». Ono było «przyczyną» wszystkiego, co istnieje. Ontyczna zależność uniwersum od absolutnego dobra pozwoliła Plotynowi wnioskować, że byt jest tożsamy z dobre. Zamienność bytu i dobra, proklamowana przez neoplatonizm, została zaakceptowana przez świętego Augustyna. Fundament dla swego aksjologicznego optymizmu znalazł on także w słowach Biblii: «Bóg widział, że wszystko, co uczynił, było bardzo dobre» (Rdz 1, 31)" (S. Kowalczyk, Człowiek i Bóg w nauce świętego Augustyna, Lublin 2007, 130). Por. tenże, Bóg jako ,Summum Bonum” w ujęciu św. Augustyna, ZNKul 4(1964) 13; J. Bussanich, Bene, w: Dizionario enciclopedico. Agostino, ed. A.D. Fitzgerald, Roma 2007, 291. 
świata - odbiciem jedności trójjedynego Boga ${ }^{31}$, zaś dobro stworzenia - objawieniem się Boga jako Dobra ${ }^{32}$.

Księżyc jako metafora Boga okazał się pomocny biskupowi Hippony do ukazania jeszcze jednego oblicza Boga Stwórcy. Augustyn w komentarzu do Psalmu 41, we fragmencie traktującym o objawieniu się Boga przez rzeczy widzialne, mówi:

„Ponieważ jednak jak jeleń pragnę źródeł wód, u niego jest źródło życia i do zrozumienia napisany został psalm synom Kore, a niewidzialne rzeczy Boże poznajemy umysłem przez to, co zostało stworzone: cóż czynię, ażebym znalazł mego Boga? Spojrzę na ziemię, ziemia została stworzona. Wielkie jest piękno ziemi, ale ma swego Artystę. [...] Spojrzę w niebo i na piękno gwiazd. Podziwiam blask słońca potrafiącego sprawić dzień, księżyc dający pociechę w ciemnościach nocy"33.

Widziany przez pryzmat wspomnianej metafory Bóg jawi się nam jako Ten, którego istotę stanowi dobroć ${ }^{34}$. Mając świadomość tego, iż Bóg nie może niczego uczynić, co byłoby niezgodne z Jego naturą ${ }^{35}$, wypada stwierdzić, iż wszystko, co zostało przez Niego stworzone jest objawieniem Bożej dobroci. Objawiona poprzez akt stworzenia księżyca dobroć Boga ${ }^{36}$, znajduje swoje potwierdzenie w przypisanej mu funkcji. Innymi słowy, księżyc jako dzieło stworzenia, którego zadaniem jest niesienie pociechy w ciemnościach nocy ma wskazywać na dobroć samego Boga. Dobroci tej nie należy jednak utożsamiać jedynie z niesieniem pociechy w utrapieniach i czasach próby. Choć

${ }^{31}$ Por. M. Krapiec - Z. Zdybicka, Augustyn. III. Myśl filozoficzna, EK I 1097.

${ }^{32}$ Należy zauważyć, iż dobra nie można jednak przypisać Bogu jako Jego cechy, gdyż jest ono tożsame z Jego naturą. W Bogu nie ma też różnicy między ontycznym a moralnym dobrem. Por. S. Jaśkiewicz, Św. Augustyn - poszukiwanie Boga, Katowice 2012, 157.

${ }^{33}$ Augustinus, Enarrationes in PS. 41, 7, CCL 38, 464: „Sed quoniam sicut cervus desidero ad fontes aquarum, et est apud eum fons vitae, et in intellectum scriptus est psalmus filiis Core, et invisibilia Dei per ea quae facta sunt intellecta conspiciuntur; quid agam, ut inveniam Deum meum? Considerabo terram: facta est terra. Est magna pulchritudo terrarum; sed habet artificem. [...] Ostendo magnitudinem circumfusi maris, stupeo, miror; artificem quaero: coelum suspicio et pulchritudinem siderum; admiror splendorem solis exserendo diei sufficientem, lunam nocturnas tenebras consolantem", thum. J. Sulowski, PSP 38, Warszawa 1986, 127.

${ }^{34}$ Według Augustyna między naturą a przymiotami zachodzi realna tożsamość. Tożsamość taka zachodzi również pomiędzy poszczególnymi przymiotami, dzięki czemu wszystkie atrybuty w równym stopniu współkonstytuują bytowość natury Bożej. Por. Augustinus, De Trinitate VI 7, 8, PL 42, 829; tenże, Sermo 341, 8, 10, PL 39, 1499. Wypada ponadto zauważyć, że istota Boża i przymioty Boże nie są ani tym samym, ani czymś różnym, jest to jedna rzeczywistość, ale tak bogata i prapierwotna, że umysł ludzki nie może jej ująć naraz. Myśl ludzka nie może wyrazić rzeczywistości Bożej jednym aktem, poznaje ją i wyraża pod różnymi aspektami i wieloma aktami; wyrazy te oddają realne treści, które jednak nie są ani synonimami, ani dywersyfikacjami. Por. C.S. Bartnik, Dogmatyka katolicka, t. 1, Lublin 1999, 124.

${ }^{35}$ Por. W. Granat, Dogmatyka katolicka, t. 1: Bóg jeden w Trójcy osób, Lublin 1962, 269.

${ }^{36}$ Por. Augustinus, Enarrationes in Ps. 134, 9, CCL 40, 1944. 
bowiem takie rozumienie dobroci wynika z symboliki nocy ${ }^{37}$, to Boża dobroć bez wattpienia wykracza poza tak zakreślony obszar działania.

2. Księżyc metaforą Chrystusa. Ukazany powyżej teologiczny wymiar symboliki księżyca znajduje swoje dopowiedzenie poprzez odniesienie księżyca do osoby Chrystusa. Ten chrystologiczny aspekt teologicznej interpretacji motywu księżyca, który dochodzi do głosu w Enarrationes in Psalmos w komentarzu do Psalmu 73, widzieć należy w kontekście rozważań mających za punkt wyjścia zagadnienie zbawienia. Świadczy o tym jednoznaczne stwierdzenie Augustyna: „Tu powinniśmy coś zrozumieć, co odnosi się do samego zbawienia" ${ }^{38}$. Augustyn, jak należałoby oczekiwać, nie podejmuje się jednak wykładni zapowiedzianego tematu. Mając natomiast na uwadze wywołaną kwestię, biskup Hippony ukierunkowuje swoje rozważania na osobę Chrystusa, który cielesnych, czyli niepojmujących mądrości, pociesza „prawdą przez objawienie ciała, niczym księżyc rozjaśniający noc"39. Powyższe słowa, zdaje się zaś dobrze tłumaczyć następująca wypowiedź Hipponaty:

„Wysilaj swój umysł ile tylko możesz. [...] Zobaczymy czy nie zadrży twój wzrok. Możesz dostrzec to, coś przed chwilą usłyszał w Ewangelii: «Na początku było Słowo, a Słowo było u Boga, a Bogiem było Słowo» (J 1, 1). [...] Czy już potrafisz pojać Słowo, nie dźwięk, ale Boga? Czy nie słyszałeś w tym kontekście: «A Bogiem było Słowo?» Ty jednak owe słowa rozważasz: «Wszystko przez nie się stało» (J 1, 3). [...] Jakimże zatem jest owe Słowo? Czy rozumiesz człowiecze cielesny? Odpowiedz: rozumiesz? Nie rozumiesz, jeszcze przynależysz do nocy. Konieczny ci jest księżyc, żebyś nie umarł w ciemnościach"40.

Ukazany za pomocą metafory księżyca Chrystus jawi się tutaj jako Słowo, które było u Boga i było Bogiem. Nie znaczy to zaś nic innego jak to, że Chrystus jest tożsamy z Bogiem Ojcem. Mając zaś na uwadze wcześniej podane określenie Chrystusa jako Tego, który pociesza ,prawdą przez objawienie ciała"41, wypada nam z kolei stwierdzić, że wraz z Jego przyjściem na świat dokonało się oznajmienie człowiekowi radosnej dla niego prawdy

\footnotetext{
${ }^{37}$ Por. tamże 91, 4, CCL 39, 1282; 97, 2, CCL 39, 1371; 1, 2, CCL 38, 1.

${ }^{38}$ Tamże 73, 19, CCL 39, 1017: „Aliquid hic intellegere debemus, quod pertineat ad ipsam salutem", PSP 39, 319.

${ }^{39}$ Tamże: ,illos consolaris carnis manifestatione, tamquam luna consolans noctem”, PSP 39, 319.

${ }^{40}$ Tamże: ,erige quantum potes mentem tuam. Videamus si pertines ad diem; iam videamus, si non palpitat aspectus tuus. Potes videre quod audisti modo ex Evangelio: In principio erat Verbum, et Verbum erat apud Deum, et Deus erat Verbum? Non nosti enim tu cogitare verba, nisi quae sonant et transeunt. Potes iam capere Verbum, non sonum, sed Deum? Annon ibi audisti: Et Deus erat Verbum? Sed tu ista verba cogitas: Omnia per ipsum facta sunt. Quale ergo illud Verbum est? Capis, o carnalis? responde; capis? Non capis, adhuc ad noctem pertines; luna tibi necessaria est, ne in tenebris moriaris", PSP 39, 319.

${ }^{41}$ Tamże: ,illos consolaris carnis manifestatione”.
} 
o jego zbawieniu, które nie pozwala, by człowiek „umarł w ciemnościach” 42 . Krótko mówiąc, opisany poprzez metaforę księżyca Chrystus jest prawdziwym Bogiem, który dzięki Wcieleniu objawił człowiekowi odwieczny planu zbawienia.

3. Księżyc metaforą Kościoła. Teologiczne treści symboliki księżyca w Objaśnieniach Psalmów nawiązują także do jego związków z Kościołem ${ }^{43}$. Augustyn wielokrotnie odwoływał się bowiem do symboliki księżyca jako obrazu Kościoła ${ }^{44}$, ubogacając dzięki temu swoją refleksję eklezjologiczną nowymi treściami. Uzasadnienie dla użycia symboliki lunarnej w odniesieniu do Kościoła, podaje Augustyn w komentarzu do Psalmu 10: „Przypominam sobie, że przyrzekłem wam w tym psalmie rozważanie na temat księżyca, który bardzo odpowiednio oznacza Kościół" ${ }^{45}$, które wcześniej zapowiadał mówiąc: „Dlaczego zaś księżyc słusznie miałby oznaczać Kościół, dokładniej można rozważyć w innym psalmie, gdzie czytamy: «Grzesznicy naciagnęli łuk, by podczas zaćmienia księżyca przeszyć strzałami tych, którzy są prawego serca»" ${ }^{46}$. Swoje rozważania, mające uzasadnić metaforyczne odniesienie księżyca do Kościoła, rozpoczyna Augustyn od stwierdzenia, które uznać należy za przejaw ówczesnej wiedzy astronomicznej. W pierwszych słowach komentarza do Psalmu 10 Hipponata wyraża bowiem przekonanie, że księżyc świeci swoim własnym światłem, które „wzrasta aż do dnia piętnastego, a potem znowu zmniejsza się do trzydziestego i przybiera formę sierpnia, aż w końcu całkowicie zanika" ${ }^{77}$. co na płaszczyźnie symboliki teologicznej pozwala mu stwierdzić, że

„Zgodnie z tą opinią księżyc w interpretacji alegorycznej oznacza Kościół, ponieważ jaśnieje on od strony duchowej, a jest ciemny od strony cielesnej. Niekiedy duchowa czesść prześwieca $w$ dobrych uczynkach ludzi, kiedy indziej jest ukryta w sumieniu i znana jest jedynie Bogu, kiedy ludzie widzą jedynie stronę cielesna, jak to ma miejsce podczas modlitwy w duszy, gdy

${ }^{42}$ Tamże: ,in tenebris moriaris”.

${ }^{43}$ Symbolikę księżyca w odniesieniu do Kościoła omówił H. Rahner, „Mysterium Lunae”. Ein Beitrag zur Kirchentheologie der Vaterzeit, ZKTh 64 (1940), 61-80 i 121-131.

${ }^{44}$ Por. Augustinus, Enarrationes in Ps. 8, 9, CCL 38, 53; 8, 12, CCL 38, 55; 10, 3, CCL 38, 75; 10, 12, CCL 38, 82; 71, 10, CCL 39, 979; 71, 11, CCL 39, 979; 103(3), 19, CCL 40, 1516; 120, 12, CCL 40, 1797-1798. Wydaje się, że Augustyn przejął ten temat od Ambrożego, a ten z kolei zaczerpnął go z nauczania Orygenesa. Por. La Chiesa da Eva alla città di Dio, a cura di A. Clerici, Roma 2000, 48; Rahner, Simboli della Chiesa, s. 216-227.

${ }^{45}$ Augustinus, Enarrationes in PS. 10, 3, CCL 38, 75: „Luna vero quam congruenter significet Ecclesiam, memini me promisisse in hoc psalmo consideraturum", tłum. J. Sulowski, PSP 37, 119.

${ }^{46}$ Tamże 8, 9, CCL 38, 53: „Cur autem luna recte significet Ecclesiam, opportunius in alio psalmo considerabitur, ubi dictum est: Peccatores intenderunt arcum, ut sagittent in obscura luna rectos corde", PSP 37, 95-96.

${ }^{47}$ Tamże 10, 3, CCL 38, 76: „,rescere usque ad quintam decimam lunam, et rursus usque ad tricesimam minui, et redire ad cornua, donec penitus nihil in ea lucis appareat”, PSP 37, 120. 
wydaje się, że nic nie robimy, kiedy rozkazuje nam patrzeć na ziemię, ale podnieść serca w górę do Pana" ${ }^{\text {48 }}$.

Kościół ten, jak należy wnioskować z powyższej wypowiedzi, posiada swą stronę duchową, która znajduje swój wyraz w dobrych uczynkach ludzi. Niekiedy jednak ta strona duchowa jest skryta w sumieniu i wie o niej tylko Bóg, na zewnątrz zaś ludzie widzą jedynie stronę cielesną, symbolizowaną przez ciemną stronę księżyca.

Optyczne zmiany intensywności światła księżyca odsłaniają jeszcze inne treści eklezjologicznej refleksji biskupa Hippony. Obraz księżyca do połowy zaciemnionego i w połowie oświetlonego, będący wynikiem kolejnych zmian jego oświetlenia, jakim podlega on w czasie swego obrotu, ma z kolei dowodzić, że świeci on światłem zapożyczonym, co według Augustyna ma oznaczać, że Kościół otrzymuje światłość od Chrystusa, swojego słońca:

„Również zgodnie z tą opinią księżyc oznacza Kościól, który nie posiada własnego światła, ale jest oświecany przez Jednorodzonego Syna Bożego, który w wielu miejscach Pisma Świętego alegorycznie jest nazywany słońcem"49.

Powyższa wypowiedź, jak nie trudno zauważyć, odzwierciedla zatem przekonanie Augustyna, iż słońce i księżyc stanowią obraz jednej tajemnicy Chrystusa i Kościoła.

Uzasadnieniem dla eklezjologicznego charakteru motywu księżyca mają być ponadto przemyślenia Augustyna dotyczące zaćmienia księżyca. Symbolika tego zjawiska wprowadza w odniesieniu do Kościoła pojęcie jego początków, wskazuje także na prześladowanie męczenników i obecność w Kościele ludzi grzesznych:

„Dalej trzeba zapytać, w jaki sposób w tym psalmie rozumie się «zaćmienie księżyca», przy którym grzesznicy gotowi są przeszywać prostodusznych strzałami. O zaćmieniu księżyca można mówić w niejeden sposób. Albowiem zarówno, gdy po zakończeniu miesięcznego obiegu znika, jak kiedy chmury zasłaniają jego blask albo kiedy w pełni jest zaćmiony, można mówić o zaćmieniu księżyca. Można to też zastosować do prześladowców męczenników, że pragną oni strzałami przeszyć prostodusznych. Odnieść można także do początków Kościoła, kiedy jeszcze w pełni nie zajaśniał na ziemi, a przeważały ciemności pogańskich zabobonów. Podobnie, kiedy niczym chmury zacieniające ziemię, języki bluźnierców i zniesławiających imię chrześci-

${ }^{48}$ Tamże, CCL 38, 76: „Secundum hanc opinionem luna in allegoria significat Ecclesiam, quod ex parte spiritali lucet Ecclesia, ex parte autem carnali obscura est: et aliquando spiritalis pars in bonis operibus apparet hominibus; aliquando autem in conscientia latet, ac Deo tantummodo nota est, cum solo corpore apparet hominibus; sicut contingit, cum oramus in corde, et quasi nihil agere videmur, dum non ad terram, sed sursum corda habere iubemur ad Dominum”, PSP 37, 120.

49 Tamże, CCL 38, 76: „Ergo et secundum hanc opinionem, luna intellegitur Ecclesia, quod suum lumen non habeat, sed ab unigenito Dei Filio, qui multis locis in sanctis Scripturis allegorice sol appellatus est, illustratur", PSP 37, 120. 
jańskie nie pozwalały dostrzec wyraźnie księżyca, czyli Kościoła. Zabijanie i wylewanie również takiej ilości krwi męczeńskiej, niczym podczas zaćmienia, zakryło krwią tarczę księżyca i od chrześcijaństwa odstraszało słabych. Podczas takiego okresu przerażenia grzesznicy miotali słowa podstępne i świętokradzkie, ażeby odstraszyć nawet tych, co są prawego serca. Można także odnieść do tych grzeszników, którzy są w Kościele, a przy nadarzającej się okazji owego zaćmienia księżyca, dopuszczają się licznych grzechów a co heretycy nam zarzucają i robią nam wyrzuty - za co odpowiedzialność powinni ponosić ich sprawcy" $"$.

Wyjaśnienie zwrotu obscura luna przywodzi Augustynowi jak widać na myśl, czas początków Kościoła na ziemi. Tak jak księżyc po nowiu powoli nabiera blasku i stopniowo coraz większa jego część zaczyna świecić, podobnie Kościół, po swoim założeniu przez Chrystusa nie zajaśniał od razu z pełną mocą, ale stopniowo nabierał siły, podczas gdy wokół panowały jeszcze ciemności pogańskich zabobonów. Zaćmienie księżyca to według Augustyna także czas prześladowań, kiedy to starano się zniszczyć ludzi prawych. Zaćmienie księżyca może jednak także symbolizować przelaną krew męczenników, która wylana w ogromnej ilości sprawiła, że Kościół utracił w oczach ludzi słabych swój pełny blask, co z kolei stało się przyczyną odejścia części wyznawców Chrystusa. Co więcej, księżyc przysłonięty chmurami ma oznaczać ludzi oczerniających Kościół, których słowa płynące ze złości i gniewu mają zniesławić chrześcijan. Zjawisko zaćmienia księżyca odnosi Augustyn przenośnie także do grzeszników. Wykorzystują oni różne okazje do popełniania grzechów, co odbiera blask Kościołowi, a tym samym stanowi okazję dla jego nieprzyjaciół do podnoszenia zarzutów przeciwko ludziom wierzącym.

Tak odczytana przez Augustyna symbolika zaćmienia księżyca nie oddaje wszystkich jego aspektów. Co więcej, odczytane w kluczu alegorycznej interpretacji wydarzenia odnoszące się do Kościoła nie są też ograniczone żadnymi ramami czasowymi. Pasmo niekorzystnych zjawisk dotyczących Kościoła, których charakter i chronologię trudno jest określić, nie powinno jednak, zda-

${ }^{50}$ Tamże 10, 4, CCL 38, 77: „Deinde quaerendum est quid in hoc psalmo accipiatur obscura luna, in qua peccatores sagittare paraverunt rectos corde. Non enim uno modo dici obscura luna potest: nam et cum finitur menstruis cursibus, et cum eius fulgor nubilo interpolatur, et cum plena deficit, dici potest obscura luna. Potest ergo et de persecutoribus martyrum intellegi, quod sagittare voluerint in obscura luna rectos corde: sive adhuc in Ecclesiae novitate, quia nondum terris maior effulserat, et gentilium superstitionum tenebras vicerat: sive linguis blasphemorum et christianum nomen male diffamantium, quasi nebulis cum terra obtegeretur, videri perspicua luna non poterat, id est Ecclesia: sive ipsorum martyrum caedibus et tanta effusione sanguinis, tamquam illo defectu et obscuratione qua cruentam faciem luna videtur ostendere, a nomine christiano deterrebantur infirmi; in quo terrore verba dolosa et sacrilega iaculabantur peccatores, ut etiam rectos corde perverterent. Potest et de his peccatoribus intellegi, quos Ecclesia continet, quod tunc inventa occasione huius lunae obscurae, multa commiserint, quae nobis opprobria nunc obiciuntur ab haereticis, cum eorum auctores ea fecisse dicantur", PSP 37, 121. 
niem biskupa Hippony, wzbudzać niepokoju, ale raczej wyzwolić w chrześcijaninie postawę zaufania wobec Boga:

„Jakkolwiek jednak ma się sprawa, jaka dokonuje się podczas zaćmienia księżyca dzisiaj, kiedy imię chrześcijańskie jest znane i wysławiane po całej ziemi, w jakim celu mam się niepokoić czymś nieznanym? Wszak «Ufam Panu» i nie słucham mówiących do mnie: «Ulatuj w góry jak wróbel. Bo oto grzesznicy naciągnęli łuk, by w czasie zaćmienia księżyca przeszywać nimi prostodusznych»" ${ }^{51}$.

Objaśnianie rzeczywistości Kościoła przy pomocy motywu księżyca ma miejsce nie tylko w komentarzu do Psalmu 10. Nowe treści o charakterze eklezjologicznym obrazowane figurą księżyca można także odnaleźć w wyjaśnieniach dotyczących Psalmu 120. Augustyn mówiąc w nich o księżycu, który świeci w nocy, wskazuje zarazem na Kościół, będący mistycznym Ciałem Chrystusa $^{52}$, którego Głową jest Chrystus:

„Maluczkim głosi się pokorę Chrystusa. [...] Dlatego też i w nocy maluczcy nie są pozostawieni sami, bo i w nocy świeci księżyc. Znaczy to, że poprzez ciało Chrystusa głoszony jest Kościół, ponieważ samo ciało Chrystusa jest Głową Kościoła" ${ }^{53}$.

Nieustanne odnawianie się księżyca i przezwyciężanie własnej ,śmierci” to z kolei dla Augustyna obraz Kościoła chwalebnego:

„Jeżeli zaś przez termin księżyc nie rozumie się śmiertelności ciała, przez którą obecnie przechodzi Kościół, lecz pojmuje się Kościół jako taki, który trwać będzie na wieki wolny od owej śmiertelności, to wyraźnie należy w taki sposób rozumieć: «Za dni jego zrodzi się sprawiedliwość i pełnia pokoju, aż zniknie księżyc», czyli jakby było powiedziane: Za dni jego zrodzi się sprawiedliwość, która przezwycięży sprzeciw i bunty ciała, i nastanie pokój do tego stopnia wzrastający i przeobfity, że aż zniknie księżyc, to znaczy wywyższony zostanie Kościół wraz z nim przez chwałę zmartwychwstania, jak to uprzedził go w tejże chwale pierworodny z umarłych, który zasiadł po prawicy Ojca (Mt 16, 19). I tak «wraz ze słońcem» trwając «przed księżycem» tam, gdzie później zostanie podniesiony również «księżyc»"s4.

${ }^{51}$ Tamże: „Sed quoquo modo se habeat quod in obscura luna factum est, nunc catholico nomine toto orbe diffuso atque celebrato, quid mihi est incognitis perturbari? In Domino enim confido; nec audio dicentes animae meae: Transmigra in montes sicut passer. Quoniam ecce peccatores intenderunt arcum, ut sagittent in obscura luna rectos corde", PSP 37, 121.

${ }^{52}$ Por. tamże 71, 8, CCL 39, 977.

${ }^{53}$ Tamże 120, 12, CCL 40, 1797-1798: „Parvulis praedicatur humilitas Christi. [...] Et ideo non relinquuntur in nocte parvuli, quia lucet et luna etiam in nocte; id est, per carnem Christi praedicatur Ecclesia, quia ipsa caro Christi caput Ecclesiae est”, PSP 41, 367.

${ }^{54}$ Tamże 71, 10, CCL 39, 979: „Sin vero vocabulo lunae, non mortalitas carnis per quam nunc transit Ecclesia, sed ipsa omnino Ecclesia significata est, quae permaneat in aeternum, ab hac mortalitate liberata; ita dictum accipiendum est: Orietur in diebus eius iustitia et abundantia pacis, 
Kościół ten będzie ogarnięty przez wieczną światłość Boga, nie posiadając już w sobie nic ze zmienności podlegającej śmierci, ale w tym samym czasie rozbłyśnie swą pełnią, istniejąc jako Kościół, który króluje na zawsze z Chrystusem $^{55}$. Kościół bowiem jako księżyc „od najmniejszego urósł, a skutkiem podlegania śmierci tego życia doczesnego niejako starzejącego się, urósł po to, żeby zbliżył się do słońca"56, czyli Chrystusa. Innymi słowy, księżyc zaciemniany i rozjaśniany, czyli Kościół, zmierza ku dopełnieniu swoich czasów, a więc do momentu, kiedy Chrystus - Słońce, rozbłyśnie pełnią swej chwały. W tym świetle Kościół zaniknie i będzie się cieszył światłością Chrystusa.

4. Księżyc metaforą czlowieka. Dość bogata, jak widać, symbolika księżyca w Enarrationes in Psalmos kryje w sobie także treści antropologiczne. Odnajdujemy je u Augustyna w komentarzu do Psalmu 60, gdzie księżyc jest symbolem znikomości, cielesności i ludzkiej śmiertelności:

„«Pomnożysz dni do dni króla, lat jego, aż do dnia pokolenia i pokolenia». Pokolenia tego i pokolenia przyszłego. Pokolenia tego, które przyrównać można do księżyca dlatego, że księżyc wschodzi, przybywa go, jest w pełni, ubywa go i zachodzi. Takimi są śmiertelne pokolenia. [...] albowiem księżyc metaforycznie w Piśmie stosuje się na określenie zmienności obecnej śmiertelności. Dlatego ten, kto wpadł w ręce zbójców szedł do Jerycha z Jerozolimy. Miasto bowiem Jerycho określone jest słowem hebrajskim, które po łacinie oznacza księżyc. Szedł więc niejako od nieśmiertelności do śmiertelności. Słusznie więc ów Adam, od którego pochodzi cały rodzaj ludzki w drodze został poraniony przez zbójców i porzucony na pół żywy (por. Łk 10, 80). Tak więc «Pomnożysz dni do dni króla, dołożysz lat jego, aż do dnia pokolenia», rozumiem pokolenia śmiertelnego" 57 .

donec extollatur luna, tamquam diceretur: Orietur in diebus eius iustitia, quae contradictionem ac rebellationem carnis vincat, et fiet pax in tantum crescens et abundans, donec luna extollatur, id est, elevetur Ecclesia, per gloriam resurrectionis cum illo regnatura, qui eam in hac gloria primogenitus a mortuis antecessit, ut sederet ad dexteram Patris; ita cum sole permanens ante lunam, quo postea extolleretur et luna", PSP 39, 279. Por. tenże, Epistula 55, 5, 8, PL 33, 208.

${ }_{55}$ Por. tenże, Enarrationes in Ps. 71, 10, CCL 39, 979. Zob. również Kaczmarek, ,,Seges Ecclesiae", s. 63.

${ }^{56}$ Augustinus, Enarrationes in Ps. 103(3), 19, CCL 40, 1516: „,rescentem de minimo, et ista mortalitate vitae quodammodo senescentem; sed ut propinquet ad solem”, PSP 41, 51.

${ }^{57}$ Tamże 60, 8, CCL 39, 770: „Dies super dies regis adicies annos eius, usque in diem generationis et generationis. Generationis huius et generationis futurae: generationis huius quae comparatur lunae, propter quod luna nascitur, crescit, perficitur, senescit et occidit; sic sunt generationes istae mortales. [...] Luna enim figurate in Scripturis pro mutabilitate huius mortalitatis ponitur. Ideo ad Iericho descendebat ille ab Ierusalem qui incurrit in latrones: quia Iericho civitas verbum est hebraeum, et interpretatur latine Luna. Descendebat ergo tamquam ab immortalitate ad mortalitatem: et merito in itinere vulneratus a latronibus et semivivus relictus est ille Adam, ex quo est totum genus humanum. Ergo dies super dies regis adicies annos eius, usque in diem generationis, generationis mortalis accipio", PSP 39, 47. O powiększającym się i zmniejszającym księżycu jako 
Do negatywnej symboliki księżyca jako znaku niestałości i zmienności człowieka, a także jego moralnej niestałości nawiązuje Augustyn także wtedy, kiedy księżyc utożsamia z ludźmi cielesnymi. Człowiek cielesny, czyli jakby niemądry, jak mówi biskup Hippony, upada, ale i on zostanie udoskonalony:

„Jeszcze jest cielesny, niech nie upada, i on zostanie udoskonalony. «Tyś uczynił słońce i księżyc». Słońce, czyli jakby mędrca, księżyc, czyli jakby niemądrego, a jednak żadnego nie opuściłeś. Albowiem jest napisane: «Mądry trwa niczym słońce; głupiec zaś zmienia się jak księżyc» (Syr 27, 12). I co znaczy, że słońce trwa, czyli, że «mądry trwa jak słońce, a głupiec zmienia się jak księżyc», czyli jeszcze cielesny, jeszcze niemądry, ma zostać opuszczony?"58.

Ciekawe znaczenie nadaje Augustyn figurze księżyca w oparciu o zjawisko nowiu księżyca, kiedy to znajduje się on między słońcem a ziemią, wobec czego nie jest on widoczny gołym okiem. Nów księżyca ma być bowiem znakiem nowego, odrodzonego dzięki łasce, życia w Jezusie Chrystusie:

„«W trąbę zagrajcie na początku miesiąca trąby». Było nakazane, żeby na początku miesiąca zagrać na trąbie. Zwyczaj ten do tej pory Żydzi zachowują zewnętrznie, nie rozumiejąc znaczenia duchowego. Początkiem bowiem miesiąca jest nów księżyca. Nów księżyca, to nowe życie. Co zatem znaczy nów księżyca? «Jeśli więc ktoś pozostaje w Chrystusie, jest nowym stworzeniem» (2Kor 5, 17). Co znaczy: «W trąbę zagrajcie na początku miesiąca trąby?» Z całą ufnością głoście nowe życie. Nie obawiajcie się hałasu życia starego" $" 59$.

symbolu ludzkiej śmiertelności mówi też Augustyn, objaśniając Psalm 71: „Jednak przez księżyc wolał wskazać na wzrost oraz zanikanie śmiertelnych. A ponadto, kiedy powiedział: «zanim powstał księżyc» chcąc w jakiś sposób wytłumaczyć, dlaczego tu wspomniał księżyc, użył «pokolenia pokoleń», jakby niejako powiedział: «Zanim powstał księżyc», to znaczy przed «pokoleniami pokoleń», które przemijają ustępowaniem i następowaniem śmiertelnych, niczym powiększaniem się i pomniejszaniem księżyca” (tamże 71, 8, CCL 39, 977: „Sed per lunam significare maluit incrementa defectusque mortalium. Denique cum dixisset, ante lunam; volens quodammodo exponere pro qua re lunam posuerit, generationes, inquit, generationum: tamquam diceret: Ante lunam, id est ante generationes generationum, quae transeunt decessione et successione mortalium, tamquam decrementis incrementisque lunaribus", PSP 39, 276).

${ }^{58}$ Tamże 73, 19, CCL 39, 1017: „Adhuc carnalis est, non deseratur, et ipse perficiatur. Tu perfecisti solem et lunam: solem, tamquam sapientem; lunam, tamquam insipientem; non tamen deseruisti. Nam ita scriptum est: Sapiens permanet sicut sol; stultus autem sicut luna mutatur. Quid ergo, quia sol permanet, id est, quia sapiens permanet sicut sol, stultus sicut luna mutatur, adhuc carnalis, adhuc insipiens deserendus est?", PSP 39, 320.

${ }^{59}$ Tamże 80, 6, CCL 39, 1123: „Tuba canite in initio mensis tubae. Praeceptum erat ut in initio mensis tuba caneretur; et hoc usque nunc Iudaei corporaliter faciunt, spiritaliter non intellegunt. Initium enim mensis, nova luna est; nova luna, nova vita est. Quid est nova luna? Si qua igitur in Christo nova creatura. Quid est: Tuba canite in initio mensis tubae? Cum tota fiducia novam vitam praedicate; strepitum vitae veteris nolite metuere”, thum. J. Sulowski, PSP 40, Warszawa 1986, 31. 
Odrodzenie to jest zaś niczym innym jak zerwaniem z dotychczasowym stylem życia, co dokonuje się z niemałą trudnością. Świadczyć o tym maja, jak się wydaje, słowa Hippończyka: „Nie obawiajcie się hałasu życia starego" 60 .

W moralny wymiar symboliki księżyca wpisane są także inne treści. Księżyc ma bowiem wskazywać człowiekowi na konieczność podejmowania przez niego nieustannego trudu uwalniania się od wad. Obowiązek ten wynikać ma zaś z faktu, iż wszystko co Bóg stworzył, w tym także człowieka i księżyc, uczynił jako dobre. Dobry zaś Bóg może być chwalony jedynie przez dobre swe dzieła, gdyż ani chciwość, ani rozwiązłość nie mogą oddawać Bogu chwały. Są one bowiem dziełem złego człowieka. Co więcej, owo pokonanie w sobie złego człowieka nie dokonuje się bez Bożej pomocy:

„Dobre bowiem jest wszystko, gdyż dobry Bóg uczynił wszystko. [...] Wszędzie wychwalają Boga dzieła Jego. [...] Chwalą niebiosa, chwalą aniołowie, chwali słońce i księżyc [...], i wszystko, co Bóg stworzył, jak słyszeliście wychwala Boga. Czy może słyszeliście tam, że chciwość chwali Boga, że wychwala Go rozwiązłość? One nie chwala, ponieważ ich nie uczynił. Wychwalają tam Boga ludzie. Stwórcą człowieka jest Bóg, chciwość jest dziełem człowieka złego. Natomiast sam człowiek jest dziełem Boga. A czego chce Bóg? Zabić w tobie to, coś ty uczynił" ${ }^{\prime 1}$.

Kontynuacją moralnego wątku motywu księżyca jest dostrzeżenie w nim przez Augustyna daru Ducha Świętego, który to dar oznacza „umiejętność poznawania według tego samego Ducha" (1Kor 12, 8). Dar ten, rozumiany jako umiejętność poznawania najbardziej elementarnych prawd Ewangelii ${ }^{62}$, ma być pomocny człowiekowi w prowadzeniu życia roztropnego:

„«Powstrzymywać się od złego», co nazwał umiejętnością, to cóż innego, niż to, żeby żyjąc pośród narodu przewrotnego i nieprawego, niejako wśród nocy tego świata, zachowywać się ostrożnie i roztropnie? (por. Hb 28, 28). Chodzi o to, żeby każdy poprzez powściaganie się od nieprawości, nie został ogarnięty przez ciemności, otoczony światłem sobie tylko użyczonego daru. Otóż, kiedy w pewnym miejscu Apostoł pragnął pokazać zgodną różnorodność łask udzieloną ludziom od Boga, te dwie przede wszystkim na pierwszym miejscu postawił: «Jednemu dany jest przez Ducha Świętego dar mądrości», co uważa równoznaczne z powiedzeniem: «Słońce, jako władzę nad dniem».

${ }^{60}$ Tamże, CCL 39, 1123: „strepitum vitae veteris nolite metuere”, PSP 40, 31.

${ }^{61}$ Tamże 128, 5, CCL 40, 1884: „quia bona sunt omnia, quia bonus Deus qui fecit omnia. [...] Undique laudatur Deus ab operibus suis [...], et caetera omnia quae Deus fecit, audistis quia laudant Deum: numquid audistis ibi quia laudat Deum avaritia, quia laudat Deum luxuria? Non laudant ista, quia non ipse illa fecit. Laudant ibi homines Deum; hominis creator est Deus. Avaritia opus est mali hominis; homo ipse opus est Dei. Et quid vult Deus? Occidere in te quod ipse fecisti”, PSP 42, 56.

${ }^{62}$ Por. E. Szymanek, Wykład Pisma Świętego Nowego Testamentu, Poznań 1990, 309. 
«Drugiemu umiejętność poznawania według tego samego Ducha» co znaczy «księżyc»" $"$.

Księżyc widoczny na sklepieniu nieba ma kierować myśl człowieka na prawdę o zmartwychwstaniu. Poprzez fazy, które przechodzi przybiera wprost rangę dowodu na zmartwychwstanie. Zanikanie widoku księżyca, który następnie w regularnych fazach ukazuje swą pełnię światła, powinno uświadamiać ludziom wyrosłym w kulturze greckiej, w której zmartwychwstanie było równoznaczne $\mathrm{z}$ absurdem ${ }^{64}$, że przywrócenie do życia zmarłego ciała nie koliduje z logicznym rozumowaniem. Fazy bowiem księżyca ilustrują prawdę, że istota żywa, a jest nią także księżyc, może istnieć na nowo. Znaczy to, że zmartwychwstanie posiada swoje analogie w przyrodzie, a tym są fazy księży$\mathrm{ca}^{65}$. Augustyn wyraża takie przekonanie w komentarzu do Psalmu 102:

„Podobnie też powiedziano o księżycu, ponieważ zmniejszony i niejako zabrany znowu się odradza i dochodzi pełni, oznaczając dla nas zmartwychwstanie. Ponownie zmniejsza się, żeby zawsze oznaczać" ${ }^{66}$.

Warto w tym miejscu zaznaczyć, iż Augustyn mówiąc o księżycu jako o symbolu zmartwychwstania jednocześnie wskazuje na zawartą w tej analogii niedoskonałość. To, co w księżycu dokonuje się w ciagu miesięcy, w zmartwychwstaniu Chrystusa dokonało się raz dla wszystkich czasów ${ }^{67}$.

Niniejszy artykuł dowodzi, że Augustyn objaśniając w Enarrationes in Psalmos teksty Psalmów nie traktuje pojawiających się w nich odniesień do księżyca jedynie jako części opisów piękna stworzonego świata, ale stara się w nim dostrzec sens ukryty, którego ujawnienie służy wykładni różnych teologicznych zagadnień. Dla biskupa Hippony księżyc jest bowiem metaforą Boga Stwórcy, Chrystusa, Kościoła oraz człowieka. W odniesieniu do Boga Stwórcy księżyc ma przypominać chrześcijanom, iż Bóg stwarzając wszystko jako do-

${ }^{63}$ Augustinus, Enarrationes in Ps. 135, 8, CCL 40, 1962: „Abstinere autem a malo, quod dixit esse scientiam, quid est aliud, quam in medio nationis tortuosae et perversae, tamquam in nocte huius saeculi, caute prudenterque versari; ut abstinendo quisque ab iniquitate non confundatur tenebris, proprii muneris luce discretus? Cum ergo quodam loco Apostolus concordem gratiarum varietatem in hominibus Dei vellet ostendere, haec in primis duo posuit dicens: Alii quidem datur per Spiritum sermo sapientiae; hoc esse arbitror: Solem in potestatem diei: Alii sermo scientiae secundum eumdem Spiritum; hoc est, lunam", PSP 42, 142.

${ }^{64}$ Por. tamże 88(2), 5, CCL 39, 1236.

${ }^{65}$ Por. Kaczmarek, „,Mysterium Lunae”, s. 48.

${ }^{66}$ Augustinus, Enarrationes in Ps. 102, 9, CCL 40, 1459: „, sicut de luna ponitur, quia deminuta et quodammodo intercepta luna rursus nascitur et impletur; et significat nobis resurrectionem; sed impleta illa non permanet; rursus minuitur, ut semper significet”, PSP 40, 384; tamże 88(2), 5, CCL 39, 1236.

${ }^{67}$ Por. Sawicka, Symbolika lunarna w średniowiecznej poezji liturgicznej, s. 14. 
bre i piękne sam jest Dobrem i Pięknem. Ponadto motyw księżyca ma wskazywać na samowystarczalność Boga, Jego wolność i niezależność. Księżyc jako metafora Chrystusa pozwala z kolei dostrzec w Nim prawdziwego Boga, który poprzez wydarzenie Wcielenia objawił człowiekowi odwieczny plan zbawienia. Eklezjologiczny wymiar symboliki księżyca wprowadza natomiast pojęcie początków Kościoła, wskazuje na jego prześladowania i obecność w nim grzesznych ludzi. Co więcej, księżyc-Kościół jest mistycznym Ciałem Chrystusa, którego Głową jest Chrystus. Jest to ponadto Kościół Chwalebny, który na zawsze będzie królował z Chrystusem. Poprzez antropologiczny wymiar figury księżyca Augustyn odsłania słuchaczom swoich kazań prawdę o ludzkiej znikomości, cielesności i śmiertelności, moralnej niestałości oraz konieczności nabywania coraz większej doskonałości przy wsparciu Ducha Świętego. Księżyc ma również kierować myśl człowieka na prawdę o zmartwychwstaniu.

\section{SYMBOLISM OF THE MOON \\ IN THE ENARRATIONES IN PSALMOS BY ST. AUGUSTINE}

\section{(Summary)}

The present article proves that Augustine, explaining in Enarrationes in Psalmos the texts of Psalms, does not treat references occurig in them, to the moon merely as a part of the descriptions of beauty of the created world, but tries to perceive in it a hidden meaning, the disclosure of which serves the interpreation of different theological questions. For the bishop of Hippo, the moon is a metaphor of God the Creator, of Christ, of the Church and of the human being. With reference to God the Creator, the moon is to remind Christians, that God creating everything as being good and beautiful, He himself is the Good and the Beauty. Furthermore, the motive of the moon is to point to God's self-sufficiency, his freedom and independence. The moon as metaphor of Christ, in turn, allows to perceive in Him the true God who, through the event of Incarnation, revealed to the human being the eternal plan of salvation. The ecclesiological dimension of the symbolism of the moon, however, introduces the concept of the beginnings of the Church, points out to its persecutions and to the presence of sinful people in it. What's more, the moon-Church is the mystical Body of Christ and Christi s its Head. It is, furthermore, a Glorious Church that will be reigning with Christ for ever. Through the antropological dimension of the figure of the moon, Augustine exposes to the listeners of his sermons the truth about human fragility, corporality and mortality, moral inconstancy and a necessity for gaining more and more perfection with the suport of the Holy Spirit. The moon is salso to direct the human thinking at the truth of resurrection.

Key words: St. Augustine, Enarrationes in Psalmos, moon, symbolism.

Słowa kluczowe: Św. Augustyn, Enarrationes in Psalmos, księżyc, symbolika. 


\section{BIBLIOGRAFIA}

\section{Źródła}

Augustinus, Confessiones, PL 32, 657-868, tłum. Z. Kubiak: Święty Augustyn, Wyznania, Warszawa 1987.

Augustinus, De Trinitate, PL 42, 819-1098, tłum. M. Stokowska: Św. Augustyn, O Trójcy Świętej, Kraków 1996.

Augustinus, Enarrationes in Psalmos, ed. D.E. Dekkers - I. Fraipont, CCL 38-40, Turnhout 1956, tłum. J. Sulowski: Św. Augustyn, Objaśnienia Psalmów, PSP 37-42, Warszawa 1986.

Augustinus, Epistula 55, PL 33, 204-223.

Augustinus, Sermo 341, PL 39, 1493-1501.

Gregorius Magnus, Moralia in Iob, PL 75, 509-1162.

\section{Opracowania}

Altaner B. - Stuiber A., Patrologia. Życie, pisma i nauka Ojców Kościoła, tłum. P. Pachciarek, Warszawa 1990.

BARDSKI K., Patristic Interpretation of the Scripture and Modern Biblical Studies. Methodological Suggestions, „Folia Orientalia” 34 (1998) 23-29.

BARTNIK C.S., Dogmatyka katolicka, t. 1, Lublin 1999.

Bussanich J., Bene, w: Dizionario enciclopedico. Agostino, ed. A.D. Fitzgerald, Roma 2007, 291-293.

Chidester D.S., The Symbolism of Learning in St. Augustine, HTR 76 (1983) 73-90.

Comeau M., Saint Augustin exégèt du quatrième Évangile, Paris 1930.

Corsato C., Biblia w interpretacji Ojców Kościoła, thum. K. Kubis, Kraków 2007.

DeRMOTT J.M., Lune - symbolisme religieux, DSp IX 1191-1194.

Doni R., Święty Augustyn. Poszukiwanie prawdy. Biografia, tłum. L. Rodziewicz, Kraków 2003.

Drobner H.R., The Fathers of the Church. A Comprehensive Introduction, transl. by S.S. Schatzmann, Peabody (Mass.) 2007.

Eliade M., Traktat o historii religii, tłum. J. Wierusz-Kowalski, Warszawa 1966.

Ferrari L.C., Symbols of Sinfulness in Book II of Augustine's „, Confessiones”, AugSt 2 (1971) 93-104.

Fiedrowicz M., Principes de l'interprétation de l'Écriture dans l'Église ancienne, Bern 1998.

Forstner D., Świat symboliki chrześcijańskiej, tłum. W. Zakrzewska - P. Pachciarek R. Turzyński, Warszawa 1990.

Granat W., Dogmatyka katolicka, t. 1: Bógjeden w Trójcy osób, Lublin 1962.

JAŚKIEwICZ S., Sw. Augustyn - poszukiwanie Boga, Katowice 2012.

KaczmareK T., „Mysterium lunae” w eklezjologii starożytnego Kościoła, „Teologia i Człowiek" 17 (2011) 43-59.

KaczmareK T., „, Seges Ecclesiae”. Eklezjalny wymiar męczeństwa w nauczaniu św. Augustyna, Toruń 2010.

KowalczyK S, Człowiek i Bóg w nauce świętego Augustyna, Lublin 2007.

KowalczyK S., Bóg jako „,Summum Bonum” w ujęciu św. Augustyna, ZNKul 4(1964) 13-22.

Krąieiec M. - ZdyBicKa Z., Augustyn. III. Myśl filozoficzna, EK I 1095-1099.

La Chiesa da Eva alla città di Dio, a cura di A. Clerici, Roma 2000. 
Lurker M., Słownik obrazów i symboli biblijnych, tłum. K. Romaniuk, Poznań 1989.

PANuś K., Historia kaznodziejstwa, Kraków 2004.

Pieszczoch S., Patrologia. Wprowadzenie w studium Ojców Kościoła, Gniezno 1998.

RAHNER H., „Mysterium Lunae”. Ein Beitrag zur Kirchentheologie der Vaterzeit, ZKTh 64 (1940) 61-131.

Rahner H., Simboli della Chiesa. L'eeclesiologia dei Padri, trad. L. Pucci - A. Pompei, Roma 1971.

Romaniuk K., Biblia u Ojców Kościoła a Ojcowie Kościoła w studium Biblii, RTK 22 (1975) z. 1, 65-74.

Sawicka J., Symbolika lunarna w średniowiecznej poezji liturgicznej, „Pamiętnik Literacki" (2002) z. 3, 5-35.

Simonetti M., L'allegoria in Celso. Filone e Origine, w: Tradizione e innovazione nella cultura greca da Omero all'eta ellenistica. Scritti in onore di Bruno Gentili, a cura di R. Pretagostini, vol. 3, Roma 1993, 1129-1141.

Simonetti M., Między dostownościq a alegoriq. Przyczynek do historii egzegezy patrystycznej, tłum. T. Skibiński, Kraków 2000.

Stanula E., Św. Augustyn, Wybór mów (kazania świateczne i okolicznościowe), w: E. Stanula, Eseje patrystyczne, oprac. I. Salamonowicz-Górska, Warszawa 2014, 377-387.

Studer B., Schola christiana. Die Theologie zwischen Nizäa und Chalcedon, Paderborn 1998.

Sulowski J., Wstęp, w: Św. Augustyn, Objaśnienia Psalmów, PSP 37, Warszawa 1986, 7-35.

Szymanek E., Wykład Pisma Swiętego Nowego Testamentu, Poznań 1990.

TrAPÈ A., Święty Augustyn - człowiek - duszpasterz - mistyk, tłum. J. Sulowski, Warszawa 1987.

Tscholl J, Gott und das Schöne beim hl. Augustinus, Heverlee - Leuven 1967.

Tscholl J., Dio e il Bello in Sant'Agostino, Milano 1996.

Turzyński P., Piękno w teologii świętego Augustyna. Próba systematyzacji augustyńskiej estetyki teologicznej, Radom 2013.

Vergés R.S., La Encarnación del Verbo y la Iglesia en San Agustin. Teología de símbolos bíblico-eclesiales, EE 42 (1967) 73-112.

Wilmart A., La tradition des grandes ouvrages de saint Augustin, IV: Les Enarrationes, w: MA II, Roma 1931, 257-315.

WiTHERUP R.D., Współczesna krytyka literacka czy powrót do egzegezy patrystycznej?, VoxP 9 (1989) t. 16, 179-190. 
